\title{
Green roof evapotranspiration rates and stormwater control under subtropical climate: a case study in Brazil
}

\section{Taxas de evapotranspiração e controle do escoamento de telhados verdes sob clima subtropical: um estudo de caso no Brasil}

\author{
Nathana Karina Swarowski Arboit ${ }^{1}$ (D), Rutineia Tassi ${ }^{2}$ (D), Tiago Liberalesso ${ }^{3}$ (D), Denise Ester Ceconi ${ }^{2}$ (D) $\&$ \\ Daniel Gustavo Allasia Piccili ${ }^{2}$ (D)
}

${ }^{1}$ Fundação Estadual de Proteção Ambiental, Porto Alegre, RS, Brasil

${ }^{2}$ Universidade Federal de Santa Maria, Santa Maria, RS, Brasil

${ }^{3}$ Instituto Superior Técnico, University of Lisbon, Lisbon, Portugal

E-mails: nathanaksa@yahoo.com.br (NKSA),rutineia@gmail.com (RT), tiago.liberalesso@tecnico.ulisboa.pt (TL),dceconi@yahoo.com.br (DEC), dallasia@gmail.com (DGAP)

Received: June 20, 2021 - Revised: August 22, 2021 - Accepted: September 10, 2021

\begin{abstract}
In this study a long-term field experiment evaluating evapotranspiration rates from irrigated and non-irrigated green roof modules, as well their impacts on stormwater control was accomplished. Six green roof modules (3 irrigated and 3 non-irrigated) vegetated with S. rupestre were monitored throughout 8 months in southern Brazil. Four non-vegetated modules ( 2 irrigated and 2 non-irrigated) were simultaneously assessed to understand the role of the vegetation in the whole process. The average evapotranspiration under water-stress (ETr) was $2.6 \mathrm{~mm}$.day ${ }^{-1}$, while mean evapotranspiration under water-abundance (ETp) was $2.8 \mathrm{~mm}$. day ${ }^{-1}$. Higher evapotranspiration rates were observed during summer, increasing the substrate storage capacity, although ETr amount along the seasons was very similar, mainly affected by climatic conditions. The long-term analysis showed that $47 \%$ of the total rainfall was converted into runoff, $21 \%$ was retained in the green roof modules and $32 \%$ was released through evapotranspiration, reinforcing the importance of vegetation as a mechanism for improving stormwater control benefits. The results of this research also allowed the establishment of a crop coefficient (Kc) time series, with a monthly average of 0.9 which permits the $S$. rupestre evapotranspiration to be preliminarily estimated by using equations developed for reference culture without the need of monitoring.
\end{abstract}

Keywords: Sedum; Climatological variables; Evaporation; Culture coefficient.

\section{RESUMO}

Neste estudo foi realizado um experimento de campo de longo prazo avaliando as taxas de evapotranspiração de módulos de telhados verdes irrigados e não irrigados, bem como seus impactos no controle de águas pluviais. Seis módulos de telhado verde (3 irrigados e 3 não irrigados) com vegetação de $S$. rupestre foram monitorados ao longo de 8 meses no sul do Brasil. Além disso, quatro módulos sem vegetação (2 irrigados e 2 não irrigados) foram avaliados simultaneamente para compreender o papel da vegetação em todo o processo. A evapotranspiração média sob condição de estresse hídrico (ETr) foi de 2,6 mm.dia ${ }^{-1}$, enquanto a evapotranspiração média sob condição de abundância hídrica (ETp) foi de 2,8 mm.dia ${ }^{-1}$. Maiores taxas de evapotranspiração foram observadas durante o verão, aumentando a capacidade de armazenamento do substrato, embora a quantidade de ETr ao longo das estações tenha sido muito semelhante, afetada principalmente pelas condições climáticas. A análise de longo prazo mostrou que $47 \%$ do total da chuva foi convertido em escoamento, $21 \%$ foi retido nos módulos de telhado verde e $32 \%$ foi liberado por evapotranspiração, reforçando a importância da vegetação como mecanismo para melhorar os benefícios de controle de águas pluviais. Os resultados desta pesquisa também permitiram o estabelecimento de uma série temporal do coeficiente de cultura $(\mathrm{Kc})$, com média mensal de 0.9 que permite estimar preliminarmente a evapotranspiração do $S$. rupestre por meio de equações desenvolvidas para cultura de referência sem necessidade de monitoramento.

Palavras-chave: Sedum; Variáveis climatológicas; Evaporação; Coeficiente de cultura. 


\section{INTRODUCTION}

Green roofs are emerging as popular Low-ImpactDevelopment (LID) techniques used to mitigate the adverse effects of urbanization and the loss of vegetated spaces (Sia, 2016). In general, the green roofs consist of different layers including a waterproofing membrane, drainage storage layer, geotextile filter, growing medium (substrate) and vegetation (Berndtsson, 2010), overlaying a traditional roof.

These systems, considered as non-intrusive (Sia, 2016), outstand with benefits in the stormwater control (Berndtsson, 2010; Mentens et al., 2006; Brandão et al., 2017). Green roofs have the potential to reduce surface runoff when compared to conventional roofs (Zhang et al., 2015; Brandão et al., 2017; Sims, 2015), due to different processes as rainfall interception by the vegetation, substrate water retention, evaporation from the substrate and plant transpiration (Stovin et al., 2012; Berretta et al., 2014). Evaporation associated with transpiration of plants, i.e., evapotranspiration (ET) is a key recovery mechanism for increasing substrate water holding capacity between rainfall events (Voyde et al., 2009) and reflects on the hydrological performance of green roofs (Berretta et al., 2014; Li \& Babcock Junior, 2014) in the runoff volume retention, besides delaying and decreasing the peak flow of discharges.

As any other vegetated surface, the loss of water from green roofs to atmosphere depends on several factors as the climate, depth and properties of the substrate layer, and water availability (Sia, 2016). Climatic variables such as temperature, relative humidity, wind speed and solar radiation interact with each other and control evapotranspiration rates (Cascone et al., 2019; Allen et al., 1998). Properties of the substrate layer and water availability (Bevilacqua et al., 2015) are also essential condition and, in some cases, even if the weather conditions are favorable for enhanced evapotranspiration during dry periods, as the substrate moisture content also decreases, evapotranspiration is reduced (Berretta et al., 2014).

In addition, other factors linked to green roofs design, including the vegetal species and its phenological stage, influence the loss of water from vegetated covers (Sims et al., 2016). Several researchers defend the genus Sedum as the ideal vegetation for extensive green roofs mainly due to the presence of Crassulacean Acid Metabolism for carbon fixation (Getter \& Rowe, 2008; Berghage et al., 2007) and shallow substrate adaptability (Monterusso et al., 2005; VanWoert et al., 2005). This metabolism allows a greater adaptability of Sedum to environmental stress situations verified in vegetation covering, reducing evapotranspiration rates during drought periods and increasing it when water is abundant (Berghage et al., 2007; Voyde, 2011). This characteristic is very important for green roofs coverage, since irrigation can be an undesirable practice from the water resources sustainability point of view.

Some studies characterized Sedum genus evapotranspiration (Berretta et al., 2014; Berghage et al., 2007; Ayata et al., 2011) by means of weighing lysimeters or by using volumetric water content sensors in the substrate layer, under controlled or uncontrolled environmental conditions. They have shown that evapotranspiration rates differ between seasons, with high values during summers and low values during winter cold conditions (Berretta et al., 2014; Poë et al., 2015; Boafo et al., 2017), suggesting that the best performance of green roofs in stormwater control can be achieved in warm periods.

Nevertheless, (Cascone et al., 2019) mentioned a knowledge gap in the literature of long-term evapotranspiration data in green roofs, including different seasons in a specific climate, once most studies report are based on a short-term monitoring. Additionally, the same authors highlight that the most part of these studies were developed in countries located in the North Hemisphere, where most Sedum species are native and green roofs are a wellaccepted and adopted practice.

Therefore, there is a lack of green roofs long-term evapotranspiration data in the Southern Hemisphere. In South America countries, green roofs researches are incipient. In Brazil, for instance, even that the usage of green roofs is being encouraged in many cities, green roofs information started to be reported in literature less than 10 years ago, and mostly focused on stormwater control (Tassi et al., 2014; Castro, 2011; Baldessar, 2012), without a detailed investigation about physical processes that can improve this results, especially the role of evapotranspiration. This absence of scientific data available to evaluate green roofs applicability to local conditions is one of the major obstacles to foster the adoption of extensive green roofs in developing countries such as Brazil, once the experiences and technology adopted from different climate regions may compromise green roofs performance (Marasco et al., 2015).

This paper presents results that provide better understanding of the long-term behavior of extensive green roofs in subtropical climate conditions, especially how evapotranspiration rates can affect stormwater control. Evapotranspiration rates of Sedum rupestre were quantified throughout eight months in experimental modules of extensive green roofs in Brazilian subtropical climate, under standard (water abundance) and non-standard (water-stress), or real conditions of cultivation, providing information for the assessment of similar green roofs.

\section{MATERIALS AND METHODS}

To achieve the purpose of this study, an eight-month record of meteorological and runoff data from six extensive green roof testbeds in a weighing lysimeter system have been analysed. In addition to the six vegetated modules with Sedum rupestre, four unvegetated modules were simultaneously monitored in an open field experiment to assess evapotranspiration rates under irrigated and non-irrigated conditions.

\section{Field experimental modules}

The experimental modules were constructed at the Federal University of Santa Maria (UFSM), city of Santa Maria, Brazil, located at $29^{\circ} 41^{\prime}$ South latitude and $53^{\circ} 48^{\prime}$ West longitude. Its altitude is about 151 m.a.s.l., comprehending Pampa and Atlantic Forest biomes, in the central region of Rio Grande do Sul, the Southernmost State of Brazil. According to Köppen's classical classification (Peel, Finlayson, McMahon, 2007), the climate of Santa Maria region is Cfa humid subtropical, and generally has hot humid summers and mild to cool winters. The average temperature 
is $19.3^{\circ} \mathrm{C}$ and the average annual rainfall is $1688 \mathrm{~mm}$, well distributed throughout the year. Evaporation rates have strong seasonality, with maximum volumes observed during the months of November, December and January, which together total approximately 35\% of the annual average evaporation, which is $906 \mathrm{~mm}$ (Instituto Nacional de Meteorologia, 2021).

The modules consisted of a polypropylene trays with surface area of $0.202 \mathrm{~m}^{2}$ ( $56 \mathrm{~cm}$ long x $36 \mathrm{~cm}$ wide x $13 \mathrm{~cm}$ height). Each tray was filled from the bottom to the top, with a $10 \mathrm{~mm}$ drainage layer made of a geotextile filter membrane, and $8 \mathrm{~cm}$ of a prepared substrate. Based on previous study in the region, the substrate was composed by local topsoil (Red-Yellow Argisol, according to Brazilian Soil Classification System - Santos et al., 2018) with $55 \%$ total porosity, vermiculite (50\% water holding capacity) and soil conditioner ( $80 \%$ total porosity) in the proportions of $3: 1: 1$, respectively. A broad description about physical, chemical, and hydraulic properties of the soil used in the substrate composition is presented in Liberalesso et al. (2021). At the bottom of the drainage layer, a drain was installed allowing the excess water to be off the modules being diverted to a storage unit.

Six modules were vegetated with the Sedum rupestre and four were left unvegetated (bare substrate), enabling evapotranspiration and evaporation evaluation. Sedum rupestre was chosen due to its adaptability to the local climatic conditions, including freezing, water shortage, and high temperatures, as previously evaluated (Tassi et al., 2014; Lorenzini Neto, 2014; Pessoa, 2016). Besides these aspects, the genes Sedum is a popular choice among extensive green roofing projects due to its tolerance for drought and shallow substrate adaptability (Getter \& Rowe, 2008; Monterusso et al., 2005; VanWoert et al., 2005; Rowe et al., 2006).

The modules were identified and allocated over two metal structures at $1.24 \mathrm{~m}$ above ground level, with a slope of $1 \%$ enabling that the flow excess be toward to the reservoir. The modules had four cables allowing them to be suspending for weighing. The Figure 1 shows the experimental set, where GRM1, GRM2, GRM3, GRM4, GRM5 and GRM6 are the Green Roofs Modules and SM1, SM2, SM3 and SM4 are the Soil Modules ones.

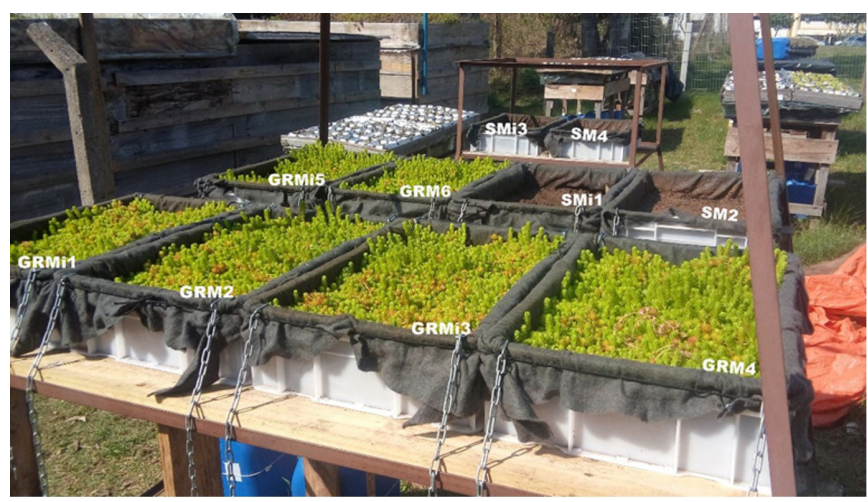

Figure 1. Experimental set up. Green Roofs Modules (GRM). Soil Modules (SM).

\section{Monitoring routine and data treatment}

The modules were treated as lysimeter systems and the daily weight difference was quantified along eight months, starting one month after vegetation establishment in July 2016 (winter) ending in February 2017 (summer). Before starting the monitoring, the modules were fully saturated until field capacity in order to provide the same initial conditions of humidity. The average field capacity was equivalent to $22 \mathrm{~kg}$ (module weight) established after total saturation and left to drain out for 24 hours (Casaroli \& van Lier, 2008). After this process, modules GRMi1, GRMi3 and GRMi5 were irrigated during the monitoring in order to maintain field capacity (water-abundance) and to keep evapotranspiration under standard, or non-stress condition (ETp). In the same way, SMi1 and SMi3 received irrigation when necessary to keep evaporation $(\mathrm{EV} \mathrm{p})$. Non irrigated vegetated modules allowed the establishment of evapotranspiration under water-stress condition (ETr), while the non-vegetated ones allowed to determine the evaporation under water-stress condition $(\mathrm{EVr})$.

Each module was daily weighed by a team of at least two people trained and responsible for accomplishing this task, and the same protocols were kept during the whole monitoring period. For weighing it was used an electronic digital scale with accuracy of $2 \mathrm{~g}$, that was in turn calibrated regularly following regulations of the United Kingdom Accreditation Service (2015), European Association of National Metrology Institutes (European Association of National Metrology Institutes, 2011) and the Brazilian National Institute of Metrology, Standardization, and Industrial Quality (Instituto Nacional de Metrologia, 1994). The monitoring was complemented with a rain gauge placed about $1.5 \mathrm{~m}$ near the experimental installation, allowing to quantify the daily rainfall volumes. The runoff (water excess) diverted from the bottom drain and stored in the reservoir was quantified by using a graduate pipette. These procedures were realized always at 4 p.m., according to time pre-established for monitoring.

The data collected from all modules were daily analyzed and the water balance Equation 1 was applied to quantify evapotranspiration (ETr and ETp) and evaporation (EVr and EVp) for each module.

$\operatorname{ETj}(E V j)=\frac{W_{j-1}+(P j \times A)+I-R j-W_{j}}{A}$

where: ET (evapotranspiration under water-stress condition or non-stress condition) is the evapotranspiration in the day $j$ ( $\mathrm{mm}$. day $\left.^{-1}\right), \mathrm{EV}_{\mathrm{j}}$ (evaporation under water-stress condition or non-stress condition) is the evaporation in the day $j\left(m m \cdot d a y^{-1}\right), W_{j-1}$ is the weight of the modules in the day ${ }_{j-1}(\mathrm{Kg}) ; \mathrm{W}_{j}$ is the weight of the module in the day $j(\mathrm{Kg}), \mathrm{R}_{\mathrm{i}}$ is the total water drained to the reservoir unit in the day $j(\mathrm{~L}) ; \mathrm{P}_{j}$ is the total rainfall in the day $j$ $\left(\mathrm{L} . \mathrm{m}^{-2}\right), \mathrm{I}$ is irrigation $(\mathrm{L}), \mathrm{A}$ is the module surface area $\left(0.202 \mathrm{~m}^{2}\right)$.

Evapotranspiration and evaporation water losses were experimentally quantified on a daily time step, which allowed further analysis considering the monthly and seasonal time scale. During the analysis, questionable daily data or failures were discarded, and cumulative values (such from weekends and holidays) were disregarded to daily time step. However, the cumulative values were maintained during monthly and seasonal time intervals analysis. 
Results obtained from evapotranspiration and evaporation were discussed based on irrigated triplicates average (GRMi1, GRMi3 and GRMi5), non-irrigated triplicates average (GRM2, GRM4 and GRM6), irrigated duplicate average (SMi1 and SMi3) and non-irrigated duplicate average (SM2 and SM4), affected by similar climatological factors. Meteorological variables as average daily wind speed (W), average daily air temperature (T), maximum daily air temperature $\left(\mathrm{T}_{\max }\right)$, minimum daily air temperature $\left(\mathrm{T}_{\min }\right)$, average daily relative humidity $(\mathrm{RH})$, average daily maximum relative $\left(\mathrm{RH}_{\text {max }}\right)$ humidity, average daily minimum relative humidity $\left(\mathrm{RH}_{\text {min }}\right)$, total daily solar radiation $\left(\mathrm{R}_{\mathrm{ad}}\right)$ and rainfall were hourly monitored at 83936 (code) a weather station belonging to INMET (Brazilian National Institute of Meteorology), located near the experimental area.

Meteorological data were also used for determination of reference crop evapotranspiration (ET) by using Penman-Monteith - FAO 56, following procedures presented in (Allen et al., 1998). By combining ET and ETp the crop coefficient $(\mathrm{Kc})$ for Sedum rupestre was evaluated along the monitoring period, according to Equation 2.

$\mathrm{Kc}=\frac{\mathrm{ETp}}{\mathrm{ETo}}$

where: $\mathrm{Kc}$ is the crop coefficient (dimensionless); $\mathrm{ET}_{\mathrm{p}}$ is the evapotranspiration measured under non-stress condition ( $\mathrm{mm}$ ); $\mathrm{ET}_{\mathrm{o}}$ is the reference crop (grass) evapotranspiration calculated using Penman-Monteith method (mm).

Descriptive statistics were used to express the evapotranspiration and evaporation findings in terms of mean, median, sum, standard deviation, minimum, maximum and percentage in the different time steps, for both standard and non-standard conditions. Daily evapotranspiration and evaporation data were tested for normality using the Shapiro-Wilk test at a significance level of 5\%. In order to verify possible significant differences between evapotranspiration and evaporation rates the Wilcoxon nonparametric test, at a significance level of $5 \%$ was applied. Evapotranspiration results taken from non-irrigated modules are presented as ETr and the irrigated ones as ETp, in the same way, evaporation rates are presented as EVr and EVp.

The stormwater control was evaluated by meaning the runoff coefficient (C), Equation 3, considering the long-term average data from vegetated non-irrigated modules, which was compared against the long-term average data from non-vegetated-non-irrigated modules.

$$
C=\frac{P_{e}}{R_{e}}
$$

where: $\mathrm{C}$ is the runoff coefficient (dimensionless), Pe is the total rainfall depth during each event ( $\mathrm{mm}$ ), and Re is the runoff volume drained at the end of each rainfall event ( $\mathrm{mm}$ ).

\section{RESULTS AND DISCUSSION}

\section{Climate characterization}

The monitoring was accomplished over eight months, beginning on July 1, 2016 ending on February 28, 2017, including representative days of winter, spring and summer in the South Hemisphere. The climatological characterization during the monitoring period is presented in Table 1, complemented with climate normal (last 30 years).

During the monitoring period, parameters such as average monthly temperatures, solar radiation and relative humidity were close to the climatological normal. Wind speed averaged $65 \%$ below the climatological normal for the region. Likewise, monthly accumulated precipitation volume was lower in December

Table 1. Climatic characterization for the study period.

\begin{tabular}{|c|c|c|c|c|c|c|c|c|c|c|c|c|}
\hline \multirow{2}{*}{\multicolumn{2}{|c|}{ Variables }} & \multicolumn{6}{|c|}{2016} & \multicolumn{2}{|c|}{2017} & \multicolumn{3}{|c|}{ Season } \\
\hline & & July & Aug & Sep & Oct & Nov & Dec & Jan & Feb & Winter & Spring & Summer \\
\hline \multirow[t]{4}{*}{ Temperature $\left({ }^{\circ} \mathrm{C}\right)$} & Climate normal & 14.1 & 14.2 & 16.5 & 18.6 & 21.0 & 23.3 & 24.2 & 23.9 & - & - & - \\
\hline & $\bar{T}$ & 13.3 & 15.4 & 14.9 & 18.4 & 20.2 & 23.3 & 24.0 & 24.0 & 14.5 & 19.5 & 23.9 \\
\hline & $\bar{T}_{\max }$ & 14.0 & 16.0 & 15.5 & 18.9 & 20.8 & 23.9 & 24.5 & 24.6 & 15.0 & 20.1 & 24.5 \\
\hline & $\bar{T}_{\min }$ & 13.0 & 14.8 & 14.3 & 17.8 & 19.6 & 22.6 & 23.4 & 23.5 & 14.0 & 18.9 & 23.3 \\
\hline \multirow{4}{*}{$\begin{array}{l}\text { Relative humidity } \\
(\%)\end{array}$} & Climate normal & 80.0 & 78.0 & 78.0 & 73.0 & 71.0 & 69.0 & 71.0 & 76.0 & - & - & - \\
\hline & $\overline{R H}$ & 85.1 & 81.9 & 80.2 & 81.4 & 74.4 & 74.5 & 84.3 & 86.0 & 83.3 & 76.1 & 85.1 \\
\hline & $\overline{R H}_{\max }$ & 87.2 & 84.7 & 83.0 & 84.0 & 77.9 & 77.6 & 87.3 & 88.9 & 85.8 & 79.2 & 88.1 \\
\hline & $\overline{R H}_{\text {min }}$ & 83.0 & 79.1 & 77.5 & 78.7 & 70.9 & 71.4 & 81.2 & 82.8 & 80.9 & 72.9 & 82.1 \\
\hline \multirow{2}{*}{$\begin{array}{l}\text { Solar radiation } \\
\left(\mathrm{MJ} \mathrm{m}^{-2} \text { day }^{-1}\right)\end{array}$} & Climate normal & 9.8 & 11.7 & 14.5 & 19.0 & 21.9 & 23.0 & 21.7 & 20.6 & - & - & - \\
\hline & $\overline{R a d}$ & 9.8 & 11.8 & 16.8 & 17.2 & 23.1 & 22.5 & 21.4 & 19.1 & 11.9 & 21.1 & 20.1 \\
\hline \multirow{2}{*}{$\begin{array}{l}\text { Wind speed } \\
\left(\mathrm{m} \mathrm{s}^{-1}\right)\end{array}$} & Climate normal & 2.9 & 2.9 & 3.1 & 3.3 & 3.2 & 3.1 & 2.9 & 2.9 & - & - & - \\
\hline & $\bar{W}$ & 2.0 & 1.8 & 2.0 & 2.3 & 2.0 & 2.1 & 2.0 & 1.7 & 1.9 & 2.1 & 1.8 \\
\hline \multirow{2}{*}{$\begin{array}{l}\text { Rainfall } \\
(\mathrm{mm})\end{array}$} & Climate normal & 144.9 & 142.1 & 124.3 & 128.2 & 120.5 & 142.2 & 163.0 & 127.2 & - & - & - \\
\hline & Total & 91.4 & 122.7 & 54.6 & 400.0 & 165.6 & 34.4 & 184.3 & 226.5 & 268.7 & 592.9 & 417.8 \\
\hline
\end{tabular}

T: Average temperature; Tmax maximum temperature; Tmin: minimum temperature; RH: relative humidity; RHmax: maximum relative humidity; RHmin: minimum relative humidity; Rad: solar radiation; W: average wind speed. 
2016 (-76\%), September 2016 (-57\%), July 2016 (-37\%) and August 2016 (-14\%); while October 2016 (212\%), November 2016 (37\%), January 2017 (13\%), and February 2017 (78\%) were higher in comparison with the climatological normal.

\section{Evapotranspiration and evaporation}

Daily rates of evapotranspiration (ETr) and evaporation $(\mathrm{EVr})$ are presented in Figure 2, accompanied by the daily rainfall throughout monitored months. Constant horizontal rates of ETr and $\mathrm{EVr}$ represents the average values of evapotranspiration and evaporation from periods corresponding to weekends and holidays when data gathering was not possible.

Water losses by evaporation from bare substrate were higher than the evapotranspiration rates along the first days after rain, usually between the first and third following dry days. Due to the water availability, absence of shading and the low albedo of the surface, it was expected that the non-vegetated modules presented this behavior, since they were directly exposed to the action of the climatological variables. These results corroborate with finding from several researches (Azeñas et al., 2018; Soulis et al., 2017; Berretta et al., 2014; Voyde, 2011; Coutts et al., 2013).

After the quick initial rate of water loss plants conserved water, and evapotranspiration was not significantly different from evaporation from bare substrate. The Figure 3 shows in detail a period of fourteen dry days of monitoring (between late September and early October 2016), where is possible to observe the exponential decreasing of water loss by evapotranspiration and evaporation.

Thereby, in the absence of water supply, the evapotranspiration decreases rapidly and may cease almost completely within a few days. To maintain substrate moisture providing vegetation survival during dry days, and to promote an extra stormwater control capacity, an alternative is to increase the storage capacity within the green roof (Li et al., 2018). Thus, in rainy periods the drainage layer can hold a greater amount of water, while in drought periods the interaction between dry substrate and the drainage layer provides moisture to the plants.

Figure 4 shows the daily variability of evapotranspiration $(\mathrm{ETr})$ and evaporation $(\mathrm{EVr}$ ) rates, where outliers corresponded to high moisture available (usually the day after the rain) and favorable weather conditions. Figure 5 shows monthly evapotranspiration, monthly rainfall and number of rainy days.

Focusing the discussion on evapotranspiration, July 2016 was a low temperatures and solar radiation's month justifying lowest observed evapotranspiration rates. Increases in evapotranspiration rates during September possible was associated to smaller rainfall volume, higher solar radiation and consecutive dry days when

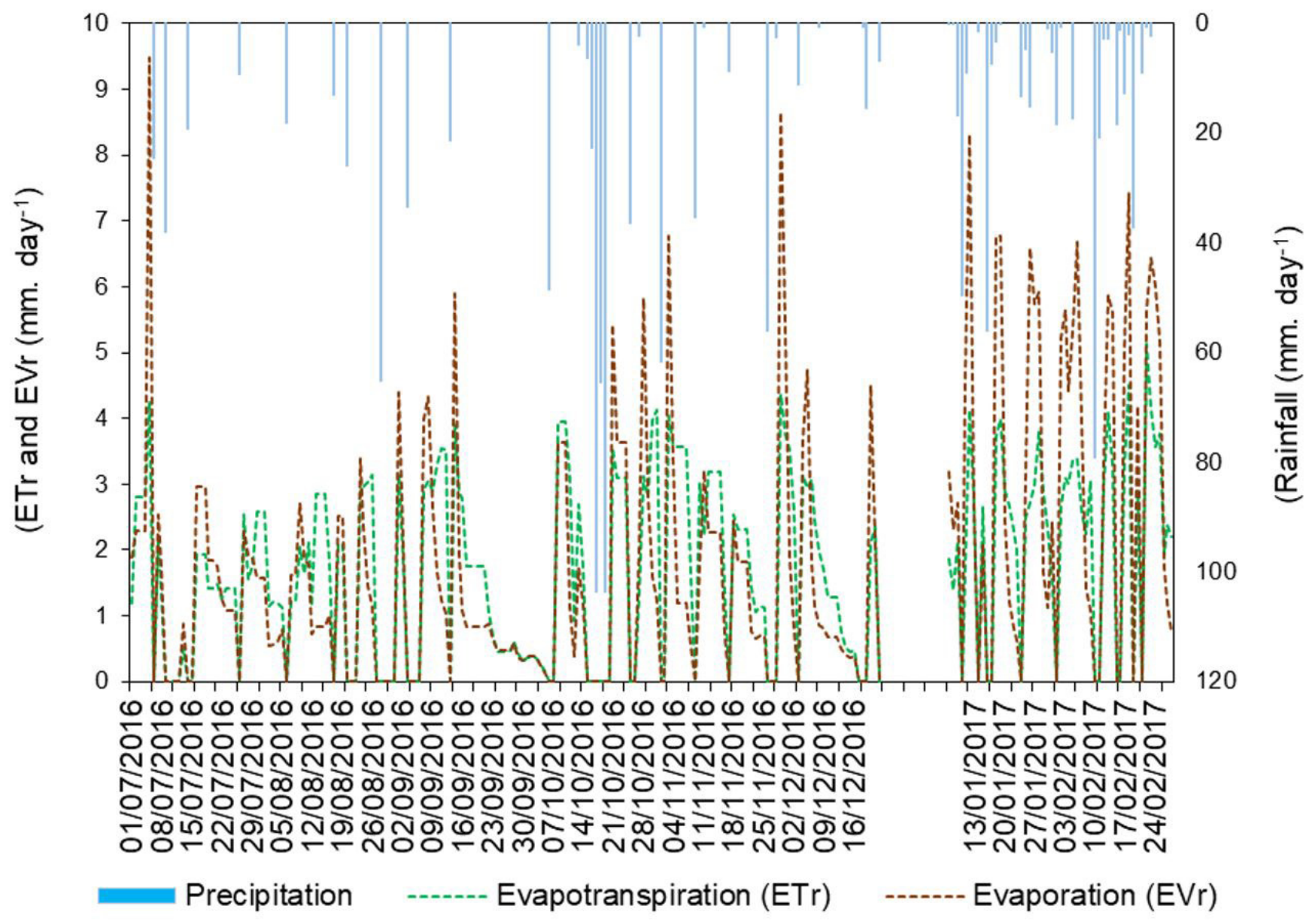

Figure 2. Daily rainfall, evapotranspiration (ETr) and evaporation (EVr) rates throughout monitored period. 
compared with previous months. Additionally, this period was coincident with vegetation growth and biomass increasing.

October 2016 was a month characterized by high daily amount of rainfall, as for instance 103,6 mm and 103,8 mm

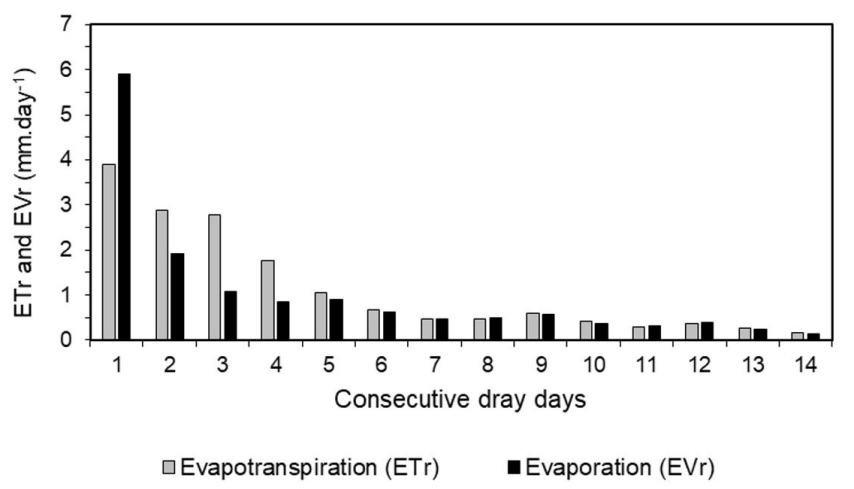

Figure 3. Evapotranspiration (ETr) and evaporation (EVr) along 14 consecutive days - from September ends to October beginning 2016.

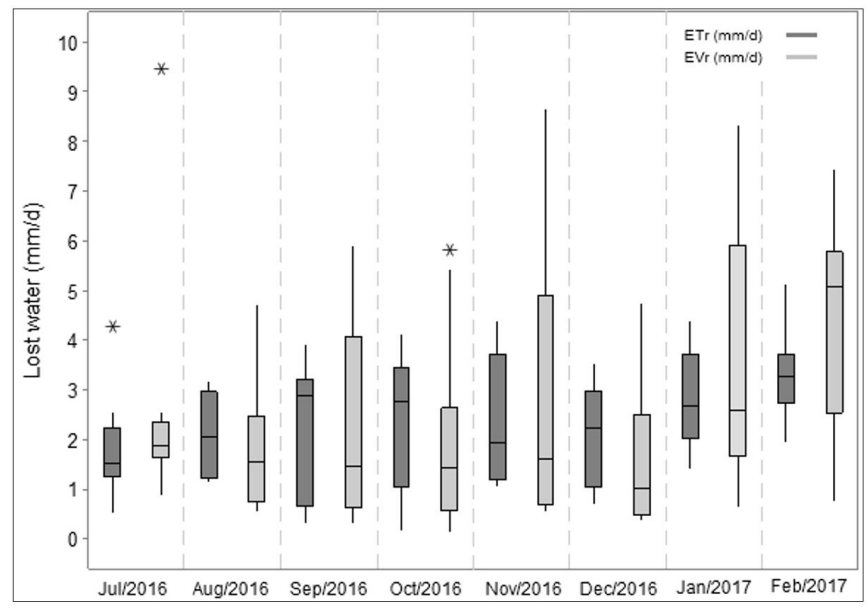

Figure 4. Daily variability of evapotranspiration (ETr) and evaporation $(\mathrm{EVr})$ along monitoring.

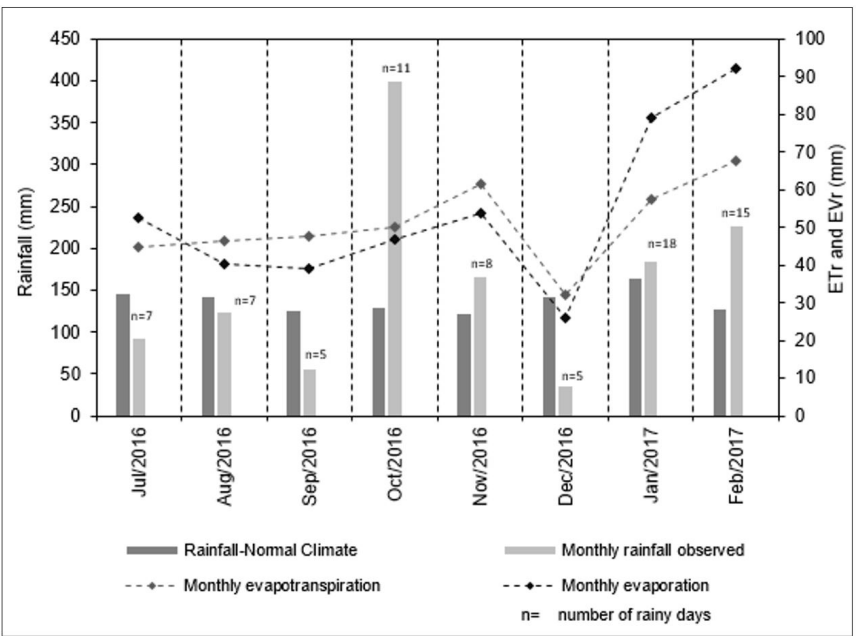

Figure 5. Monthly evapotranspiration (ETr), evaporation (EVr), rainfall and rainy days along monitoring. recorded on days $17^{\text {th }}$ and $19^{\text {th }}$, respectively, and few consecutive dry days and high solar radiation. Solely the total rainfall volume monitored in this month corresponded to approximately $31 \%$ of the total rainfall volume observed along the monitoring period. The period from October until mid-November was coincident with the flowering phase of Sedum rupestre, and once floral parts also are endowed with stomata (Appezzato-da-Glória \& CarmelloGuerreiro, 2006), this condition may increase the evapotranspiration as observed in Figure 4 and Figure 5.

Although climatic conditions (mainly solar radiation, relative humidity, and temperature) were favorable to water losses, December 2016 showed a slight reduction in evapotranspiration. This suggests that other factors, most likely inherent to vegetation, may have influenced this response. In fact, along these months Sedum rupestre was experiencing the senescence phase and cell death, which occur due to hormonal changes and environmental factors. This phase is often marked by leaf abscission or loss (Taiz \& Zeiger, 2004), which reduces leaf area and, consequently, the proportion of transpiration (Li et al., 2018). After senescence, the remaining vegetation stagnated its development, presenting leaves concentrated only at the stem apex, exposing the substrate.

The following months of January and February 2017 were marked by frequent rains, nevertheless, increases in evapotranspiration were observed possible due to high solar radiation and temperature. The substrate exposure possible increases the portion of evaporation in this process, as is possible to observe in February, when comparing evaporation against evapotranspiration.

Months with the most proportion of rainfall converted into evapotranspiration were sequentially December $(92,9 \%)$, September (87.1\%), July (49.0\%), August (37.7\%), November (37.2\%), January (31.1\%), February (29.8\%) and October (12.5\%).

Regarding seasonal analysis, Figure 6 shows the daily evapotranspiration and evaporation. This figure highlights higher evapotranspiration rates in summer, which is justified by suitable climate conditions (as shown in Table 1) and possibly, due to the higher substrate exposure in this period. In the spring, although the weather conditions were more favorable in relation to winter, evapotranspiration was slightly lower. Factors as a long period of 18 consecutive dry days with evapotranspiration rates reaching almost zero, and a frequent and large amount of rainfall may also have impaired the evapotranspiration process. These results agree with (Lazzarin et al., 2005) findings, which compared the evapotranspiration in winter against the evapotranspiration in summer and concluded that, despite lower solar irradiance in winter, the evapotranspiration was also appreciable.

Regarding evapotranspiration rates performed for a seasonal analysis, high daily rates and variability were observed during summer (Figure 6a). During winter the proportion of rainfall converted into evapotranspiration was $49.8 \%$, against $25.0 \%$ during spring and $29.9 \%$ on summer (Figure 6b). This proportions reinforces the idea that evapotranspiration is influenced by the precipitation behavior, since even winter presented the most unfavorable weather conditions (temperature and radiation) compared to other seasons. These results are proper with conclusions by authors as (Jim \& Tsang, 2011).

Table 2 presents descriptive statistics for evapotranspiration and evaporation rates under standard and non-standard conditions, 
allowing to evaluate how these rates could be increased by irrigation (water-availability).

When comparing $\mathrm{ET}_{\mathrm{p}}$ against $\mathrm{ET}_{\mathrm{r}}$, and $\mathrm{EV}_{\mathrm{p}}$ against $\mathrm{EV}_{\mathrm{r}}$, is possible to observe little differences between the results. Possibly frequently rainfall along the monitoring promoted a good water supply for non-irrigated modules, making their behavior close to the irrigated ones.
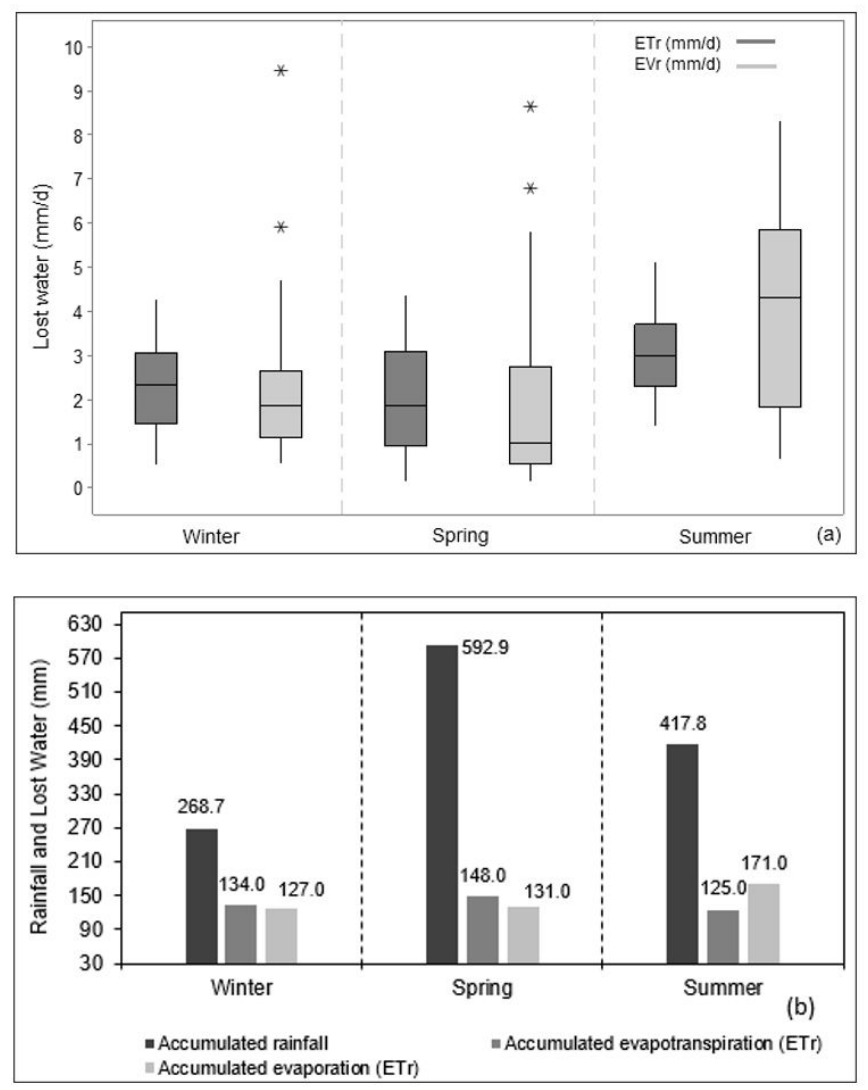

Figure 6. (a) Daily variability of evapotranspiration (ETr) and evaporation $(\mathrm{EVr})$ along the seasons and amount of rainfall, evapotranspiration and evaporation along the seasons (b).
Furthermore, the substrate features, including its physicalchemical characteristics can have somehow affected the water holding capacity (Liberalesso et al., 2021; Tan et al., 2017; Stovin et al., 2015; Berretta et al., 2014; Getter \& Rowe, 2008) and consequently the evapotranspiration rates (Cascone, 2019; Djedjig et al., 2012). Thus, engineered substrates, optimized construction and irrigation conditions can enhance the green roof evapotranspiration and its environmental benefits (Kaiser et al., 2019).

\section{Culture coefficient (Kc) for Sedum rupestre establishment}

Despite little differences between standard and non-standard condition for evapotranspiration, the ET $\mathrm{p}_{\mathrm{p}}$ results previously presented allowed the establishment of the long-term Crop Coefficient (Kc) for Sedum rupestre. This analysis was accomplished by the relationship between ET and ET estimated by the Penman-Monteith-FAO equation. The knowledge of this parameter makes possible the estimative of ET by using classical evapotranspiration equations without the need of monitoring.

Figure 7 shows the Kc long-term time series where highest values occur during the three first monitoring months (July to September), characterized by vegetative and growing phase after transplanting. Since flowering, which began in October 2016, Kc values tended to fall with senescence, which began in November 2016. Slight increasing in Kc was observed between January and February 2017, possibly due to the higher exposure of the substrate which increased the amount of evaporation in the evapotranspiration process.

The long-term average Kc was 0.9, ranging from 0.5 to 1.4. These results agree with (Schneider et al., 2011) which found Kc ranging from 1.3 to 1.4 for a composition of Sedum, in subtropical humid climate in Villanova, Pennsylvania-US. In the same way, (Voyde, 2011) found an average Kc of 1.01 for the specie Disphyma australe and 0.85 for the Sedum mexicanum, in subtropical climate with hot and humid summers and mild winter in Auckland, NZ.

Lower ranging $\mathrm{Kc}$ values were obtained for different species as 0.21 to 0.50 for Sedum album species, 0.25 to 0.71 for

Table 2 - Descriptive statistics for evapotranspiration and evaporation under standard and non-standard condition.

\begin{tabular}{|c|c|c|c|c|c|c|c|c|c|c|c|c|c|c|c|c|c|c|c|c|}
\hline \multirow[t]{2}{*}{ Time } & \multicolumn{4}{|c|}{$\begin{array}{c}\text { Mean } \\
\left(\mathrm{mm} \mathrm{day}^{-1}\right)\end{array}$} & \multicolumn{4}{|c|}{$\begin{array}{c}\text { Median } \\
\left(\mathrm{mm} \mathrm{day}^{-1}\right)\end{array}$} & \multicolumn{4}{|c|}{$\begin{array}{c}\text { Standard Deviation } \\
\left(\mathrm{mm} \mathrm{day}^{-1}\right)\end{array}$} & \multicolumn{4}{|c|}{$\begin{array}{l}\text { Minimum } \\
\left(\mathrm{mm} \mathrm{day}^{-1}\right)\end{array}$} & \multicolumn{4}{|c|}{$\begin{array}{l}\text { Maximum } \\
\left(\mathrm{mm} \text { day }^{-1}\right)\end{array}$} \\
\hline & $\mathbf{E T}_{\mathrm{p}}$ & $\mathrm{ET}_{\mathrm{r}}$ & $\mathrm{EV}_{\mathrm{p}}$ & $\mathrm{V}_{\mathrm{r}}$ & $\mathrm{ET}_{\mathrm{p}}$ & ET $_{r}$ & $\mathbf{E V}_{\mathrm{p}}$ & $\overline{E V_{r}}$ & $\overline{E T_{p}}$ & $\mathbf{E T}_{\mathrm{r}}$ & $\mathrm{EV}_{\mathrm{p}}$ & $E V_{r}$ & $\overline{E T_{p}}$ & $\mathbf{E T}_{\mathrm{r}}$ & $\mathbf{E V}_{\mathrm{p}}$ & $E v_{r}$ & $\overline{\mathrm{ET}_{\mathrm{p}}}$ & $\mathbf{E T}_{\mathrm{r}}$ & $\mathrm{EV}_{\mathrm{p}}$ & $\mathrm{EV}$ \\
\hline July/16 & 1.8 & 1.8 & 20 & 26 & 16 & 1.5 & 79 & 10 & 1.1 & 11 & & & 0.5 & & & & 4.3 & & & 9.5 \\
\hline & 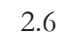 & 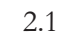 & & & & 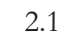 & & & 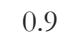 & & & & & & & & 3.8 & & & 4.7 \\
\hline $\mathrm{p} / 2$ & 3.4 & 2.2 & & & .5 & 2.9 & & & 0.8 & & 1. & & 3 & 0 & & & .0 & & & 5.9 \\
\hline ( & 3 & 2.3 & & 2 & 4 & 2.7 & 3 & 1.4 & 0.8 & & 10 & & 0.7 & 2 & & & .3 & & & 5.8 \\
\hline ov/ & 2.5 & 2 & & 28 & 4 & 1.9 & 2. & 1 & 1.0 & & 2. & 2. & 1.1 & 1 & 0 & & 4.6 & 4.4 & 1 & 8.7 \\
\hline l & 2.4 & 2 & & & 2.7 & 2.2 & 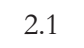 & 1 & .7 & & 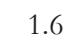 & 1. & 0.5 & 0. & & & 3.1 & & & 4.7 \\
\hline & & & & & .0 & 2.7 & 2. & 2. & .3 & & 2. & 2. & 0.0 & & & & 4.6 & & & 8.3 \\
\hline $\mathrm{eb} / 17$ & 3.6 & 3.3 & & & 3.6 & 3.3 & & 5.1 & 1.0 & & 2. & 2. & 2.0 & 1. & 0. & 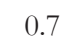 & 6.2 & 5.1 & .4 & 7.4 \\
\hline inter & 2.6 & 2.3 & & 2.3 & 2.6 & 2.3 & 3. & 1.9 & 1.0 & 0.1 & 1.2 & 1.8 & 0.5 & 0.5 & 0.9 & 0 . & 4.6 & 4.3 & 5.8 & 9.5 \\
\hline & 2.6 & 2.0 & & & & 1.8 & & 1. & 0.9 & & 1. & 2. & 0.5 & 0 . & 0 . & 0 . & 4.6 & 4.4 & 8.1 & 8.7 \\
\hline Summer & 3.1 & 3.0 & 3.9 & 4.0 & 3.3 & 3.0 & 4.0 & 4.3 & 1.3 & 0.9 & 2.2 & 2.3 & 0.0 & 1.4 & 0.7 & 0.6 & 6.2 & 5.1 & 8.5 & 8.3 \\
\hline
\end{tabular}

ET: Evapotranspiration under standard condition; $\mathrm{EV}_{\mathrm{p}}$ : evaporation under standard condition; $\mathrm{ET}_{\mathrm{r}}$ : Evapotranspiration under non-standard condition; $\mathrm{EV}_{\mathrm{r}}$ : Evaporation under non-standard condition. 
Phedimus kamtschaticus and 0.22 to 0.55 for Sedum sexagulare in humid subtropical climate in Maryland City, USA (Starry et al., 2016). Additionally, (Tabares-Velasco \& Srebric, 2012) obtained values between 0.29 and 0.59 for a vegetated roof with a succulent composition in Salt Lake City, USA, which has a hot, humid summer with no storm prevalence.

These high variability in $\mathrm{Kc}$ values among regions and species highlight the need of appropriate establishment of this parameter as accomplished in this study, providing accurate information for best estimates of evapotranspiration by using equations.

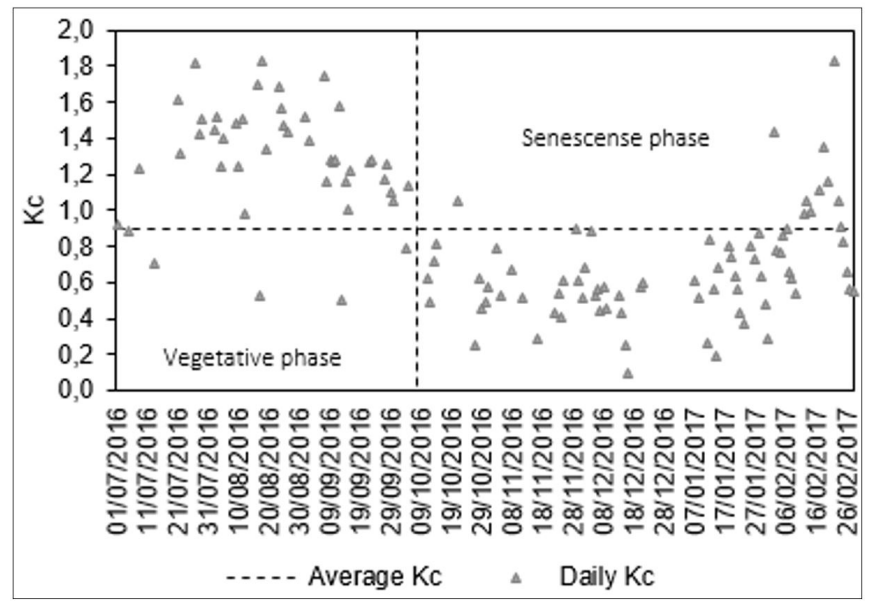

Figure 7. Long-term daily Kc time series for Sedum rupestre.

\section{Stormwater control}

Considering the amount of rainfall along the monitoring period, the average runoff coefficient from vegetated modules resulted in 0.47 (47\%). Additionally, it was evaluated that $32 \%$ of the amount of rainfall returned to the atmosphere through evapotranspiration (ETr), and 21\%, possibly, was stored in the substrate layer. For the non-vegetated modules, the average runoff coefficient was $0.43(43 \%), 34 \%$ was evaporated and $23 \%$, possibly, was stored in the substrate layer. Figure 8 shows the monitored rainfall events, as well as the runoff coefficient for each event, both for vegetated and non-vegetated modules.

These results show that both vegetated and non-vegetated modules presented very similar performance in stormwater control, confirming the results of (Soulis et al., 2017; Li et al., 2018). Nonvegetated modules had a slightly higher performance on stormwater control, possible due to the storage capacity be quickly recovered after subsequently rainy events in view of substrate exposure. Similar results were found by (Berretta et al., 2014) which state that vegetated roofs are better for keep soil moisture, however, they are less efficient in control the runoff during frequent rainy when compared with non-vegetated roofs. This conclusion does not consider other benefits provided by vegetated roofs, such as aesthetic aspects, control of soil loss, increase of biodiversity, among others, which are achieved with vegetation.

In addition, the physiological characteristics of Sedum rupestre may also have influenced the inferior performance of

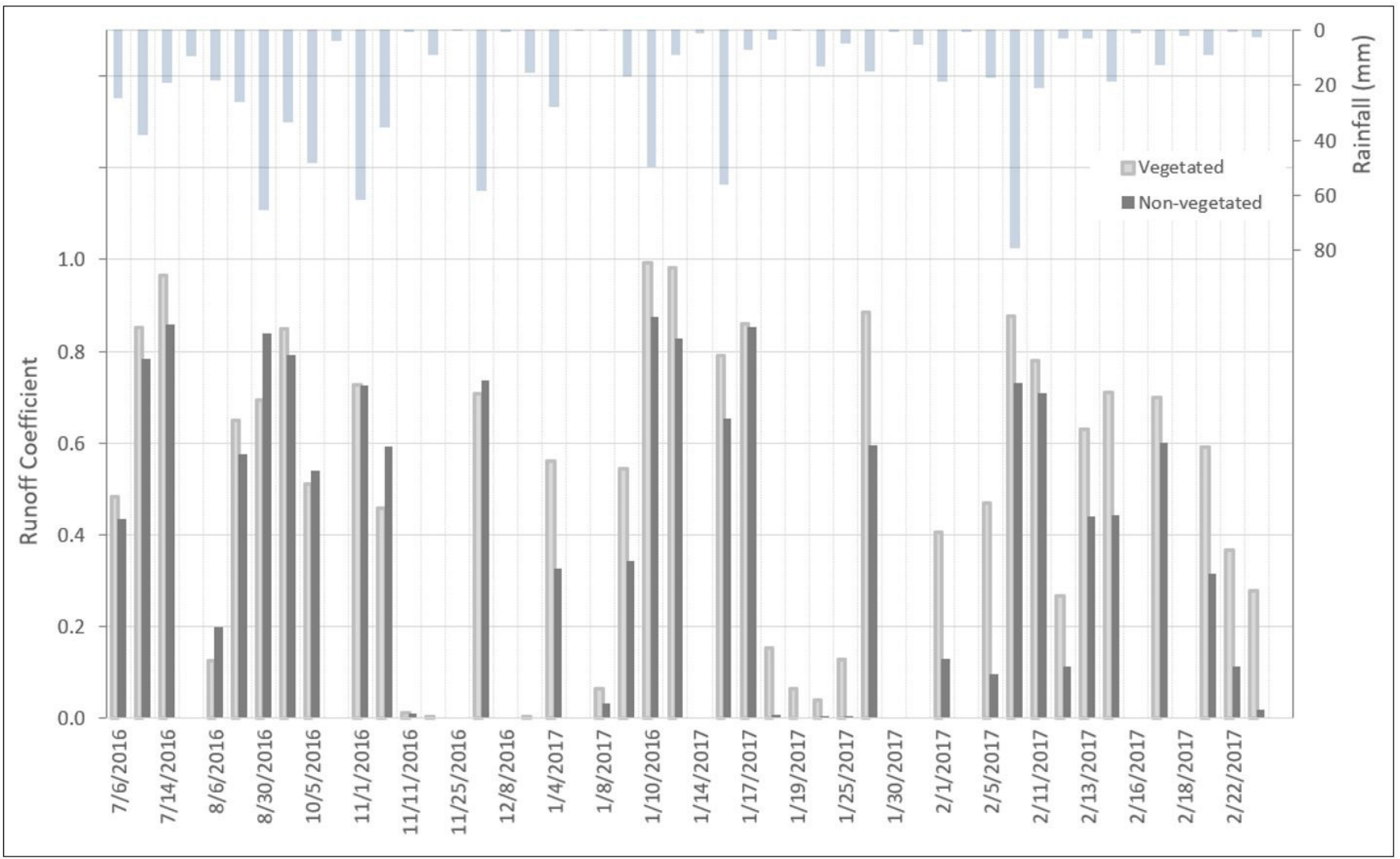

Figure 8. Runoff coefficient variability throughout the monitored events. 
vegetated modules. Species of genus Sedum have a small leaf area, shallow roots, and Crassulacean Acid Metabolism. This metabolism allows Sedum to open their stomata at night, when air temperatures are cooler and water vapor pressure deficits are lower, and close during the day in order to decrease water loss (Al-Busaidi et al., 2013). Thus, although this genus is interesting for green roofs application because it is resistant to drought periods (Getter \& Rowe, 2008) its contribution on stormwater control is low when compared to other species (Soulis et al., 2017; Li et al., 2018; Tabares-Velasco \& Srebric, 2012).

Based on these considerations, if the aiming is to increase the efficiency on stormwater control, it is recommended to identify other species of plants. In this case, is suggested the usage of native plants, adapted to the local climatological conditions with the ability for quickly recovering the storage capacity of substrate.

\section{CONCLUSIONS}

This study aimed to evaluate the evapotranspiration behavior of extensive green roofs vegetated with Sedum rupestre species. Based on open-field monitoring of experimental modules along eight months, it was concluded that evapotranspiration rates are significantly variable over the course of the day, dependent on the weather conditions, water availability in the substrate layer and the phase of vegetation development.

After rainy events, evapotranspiration rates were high due to substrate water availability. Over dry periods an exponential decay in these rates was observed, as a result of lower water availability. This finding sustains that when Sedum rupestre experiences a water shortage period, evapotranspiration is decreased as a way for maintaining water reserves to ensure plant survival during critical periods.

Reflecting the physiological behavior exposed above, the non-vegetated modules produced slightly smaller runoff than the vegetated ones, without significant statistical difference. Probably, the shading effect provided by the vegetation, the shallow root system of the Sedum rupestre and the intrinsic characteristic of the genus of water-storing leaves and stems, made difficult the process of recovering substrate's storage capacity. This behavior is not desirable when the objective is to promote stormwater control by using green roofs. However, maintaining the aesthetic aspects of green roofs in dry periods is also a factor that must be taken into consideration, and in this case the Sedum rupestre proves to be a suitable specie.

For future research, the challenge is to investigate the behavior of evapotranspiration using species with different anatomical structures and physiological characteristics that ensure both stormwater control and aesthetic benefits. In addition, substrate thickness, its physical-chemical characteristics may also influence the water holding capacity, the plant development and, consequently, water loss through evapotranspiration. Thus, an investigation about the influence of different substrate types and its depths on the Sedum rupestre response to this portion of the water balance in green roofs is another knowledge gap to be filled.

Climatic characteristics such as the frequency and rainfall volume during the monitoring period also influenced the evapotranspiration amounts. Spring and summer were the wettest seasons and, although the weather conditions were favorable, evapotranspiration amount in these seasons was very close to the winter one. Possibly low rainfall amounts and few rainy days during winter have promoted conditions to increase the Sedum rupestre evapotranspiration. In this sense, the stormwater control promoted by green roofs can be compromised when applied in regions with high amount of rain, or subjected to large periods of consecutive rainy days, which leads to the need of the development of a green roof design focused on the specificity of each location. The influence of other climatological variables (solar radiation, temperature, relative humidity, wind speed and vapor pressure deficit) on evapotranspiration rates was not evident, and the statistical correlations were mostly weak and moderate. Under field conditions possibly the influence of individual weather factors will be lost due to the interaction between all variables.

Additionally, higher evapotranspiration rates were observed in the vegetative and reproductive phases of the Sedum rupestre due to its intense structural development, especially of the root system and leaves. The evapotranspiration decrease was observed during senescence, due to leaf abscission or loss. These long-term vegetation stages should also be considered when assessing the feasibility of using Sedum rupestre as green roof vegetation, in function of the intended benefits.

In this sense, this study established a time series of crop coefficient $(\mathrm{Kc})$ values. This time series makes it possible to determine Sedum rupestre evapotranspiration to climatically similar locations by applying classical equations such as Penman-Montheith, set for a reference crop, without the need of monitoring a green roof. Although determined with great effort, it is recognized the need for refinement and validation of these values through a longer monitoring period, which covers all phases of vegetation development, also including the analysis of its interannual variability and in other climatic regions.

\section{ACKNOWLEDGMENTS}

This study was financed in part by the Coordenação de Aperfeiçoamento de Pessoal de Nivel Superior - Brasil (CAPES) - Finance Code 001, UFSM and CNPQ. The authors would like to thank the graduate program in Civil Engineering at the Federal University of Santa Maria (PPGEC/UFSM) for the support.

\section{REFERENCES}

Al-Busaidi, A., Yamamoto, T., Tanak, S., \& Moritani, S. (2013). Evapotranspiration of Succulent Plant (Sedum aizoonvar. floibundum). In S. Alexandris (Ed.), Evapotranspiration: an overview. London: IntechOpen.

Allen, R. G., Pereira, L. S., Raes, D., \& Smith, M. (1998). Crop evapotranspiration - Guidelines for computing crop water requirements- FAO Irrigation and drainage paper 56. Rome: FAO.

Appezzato-da-Glória, B., \& Carmello-Guerreiro, S. M. (Eds.), (2006). Anatomia vegetal (2. ed.). Viçosa: Ed. UFV. 
Ayata, T., Tabares-Velasco, P. C., \& Srebric, J. (2011). An investigation of sensible heat fluxes at a green roof in a laboratory setup. Building and Environment, 46(9), 1851-1861. http://dx.doi.org/10.1016/j. buildenv.2011.03.006.

Azeñas, V., Janner, I., Medrano, H., \& Gulías, J. (2018). Performance evaluation of five Mediterranean species to optimize ecosystem services of green roofs under water-limited conditions. Journal of Environmental Management, 212, 236-247. PMid:29438929. http:/ / dx.doi.org/10.1016/j.jenvman.2018.02.021.

Baldessar, S. M. (2012). Telhado verde e sua contribuição na redução da vazão da água pluvial escoada (dissertação de mestrado). Universidade Federal do Paraná, Curitiba.

Berghage, R., Jarret, A., Beattie, D., Kelley, K., Husain, S., Rezaei, F., Long, B., Negassi, A., \& Cameron, R. (2007). Quantifying evaporation and transpirational water losses from green roofs and green roof media capacity for neutralizing acid rain. USA: EPA.

Berndtsson, J. C. (2010). Green roof performance towards management of runoff water quantity and quality: a review. Ecological Engineering, 36(4), 351-360. http://dx.doi.org/10.1016/j. ecoleng.2009.12.014.

Berretta, C., Poë, S., \& Stovin, V. (2014). Moisture content behaviour in extensive green roofs during dry periods: the influence of vegetation and substrate characteristics. Journal of Hydrology (Amsterdam), 511, 374-386. http://dx.doi.org/10.1016/j. jhydrol.2014.01.036.

Bevilacqua, P., Coma, J., Pérez, G., Chocarro, C., Juárez, A., Solé, A., De Simone, M., \& Cabeza, L. F. (2015). Plant cover and floristic composition effect on thermal behaviour of extensive green roofs. Building and Environment, 92, 305-316. http:/ /dx.doi. org/10.1016/j.buildenv.2015.04.026.

Boafo, F. E., Kim, J.-T., \& Kim, J-H. (2017). Evaluating the impact of green roof evapotranspiration on annual building energy performance. International Journal of Green Energy, 14(5), 479-489. http://dx.doi.org/10.1080/15435075.2016.1278375.

Brandão, C., Cameira, M., Valente, F., Cruz de Carvalho, R., \& Paço, T. A. (2017). Wet season hydrological performance of green roofs using native species under Mediterranean climate. Ecological Engineering, 102, 596-611. http://dx.doi.org/10.1016/j. ecoleng.2017.02.025.

Casaroli, D., \& van Lier, Q. J. (2008). Critérios para determinação da capacidade de vaso. Revista Brasileira de Ciência do Solo, 32(1), 59-66. http://dx.doi.org/10.1590/S0100-06832008000100007.

Cascone, S. (2019). Green roof design: state of the art on technology and materials. Sustainability, 11(11), 3020. https://doi. org/10.3390/su11113020.

Cascone, S., Coma, J., Gagliano, A., \& Pérez, G. (2019). The evapotranspiration process in green roofs: a review. Building and Environment, 147, 337-355. http://dx.doi.org/10.1016/j. buildenv.2018.10.024.

Castro, A. S. "Uso de pavimentos permeáveis e coberturas verdes no controle quali-quantitativo do escoamento superficial urbano [Permeable pavement and green roofs in the quali-quantitative stormwater runoff control] (In Portuguese)," Federal University of Rio Grande do Sul, 2011.

Coutts, A. M., Daly, E., Beringer, J., \& Tapper, N. J. (2013). Assessing practical measures to reduce urban heat: green and cool roofs. Building and Environment, 70, 266-276. http://dx.doi. org/10.1016/j.buildenv.2013.08.021.

Djedjig, R., Ouldboukhitine, S.-E., Belarbi, R., \& Bozonnet, E. (2012). Development and validation of a coupled heat and mass transfer model for green roofs. International Communications in Heat and Mass Transfer, 39(6), 752-761. http://dx.doi.org/10.1016/j. icheatmasstransfer.2012.03.024.

European Association of National Metrology Institutes EURAMET. (2011). Guidelines on the calibration of non-automatic weighing instruments. Versão 3.0. Germany: EURAMET.

Getter, K. L., \& Rowe, D. B. (2008). Media depth influences Sedum green roof establishment. Urban Ecosystems, 11(4), 361-372. http:/ / dx.doi.org/10.1007/s11252-008-0052-0.

Instituto Nacional de Meteorologia - INMET. (2021). Normais climatológicas. Retrieved in 2021, June 20, from https:/ / portal.inmet. gov.br/servicos/normais-climatol\% $\%$ C3\%B3gicas

Instituto Nacional de Metrologia - INMETRO. (1994). Portaria INMETRO no 236 de 22 de dezembro de 1994. Aprovação do Regulamento Técnico referente à fabricação, instalação e utilização de instrumentos de pesagem não automáticos. Diário Oficial [da] República Federativa do Brasil, Brasília.

Jim, C. Y., \& Tsang, S. W. (2011). Biophysical properties and thermal performance of an intensive green roof. Building and Environment, 46(6), 1263-1274. http://dx.doi.org/10.1016/j.buildenv.2010.12.013.

Kaiser, D., Köhler, M., Schmidt, M., \& Wolff, F. (2019). Increasing evapotranspiration on extensive green roofs by changing substrate depths, construction, and additional irrigation. Buildings, 9(7), 173. https://doi.org/10.3390/buildings9070173.

Lazzarin, R. M., Castellotti, F., \& Busato, F. (2005). Experimental measurements and numerical modelling of a green roof. Energy and Building, 37(12), 1260-1267. http://dx.doi.org/10.1016/j. enbuild.2005.02.001.

Li, X., Cao, J., Xu, P., Fei, L., Dong, Q., \& Wang, Z. (2018). Green roofs: effects of plant species used on runoff. Land Degradation \& Development, 29(10), 3628-3638. http://dx.doi.org/10.1002/ldr.3102.

Li, Y., \& Babcock Junior, R. W. (2014). Green roof hydrologic performance and modeling: a review. Water Science and Technology, 
69(4), 727-738. PMid:24569270. http://dx.doi.org/10.2166/ wst.2013.770.

Liberalesso, T., Tassi, R., Ceconi, D. E., Allasia, D. G., \& Arboit, N. K. S. (2021). Effect of rice husk addition on the physicochemical and hydrological properties on green roof substrates under subtropical climate conditions. Journal of Cleaner Production, 315, 128133. https://doi.org/10.1016/j.jclepro.2021.128133.

Lorenzini Neto, F. (2014). Modelagem de telhado verde: uma análise da eficiência no controle do escoamento pluvial em diferentes escalas (dissertação de mestrado). Universidade Federal de Santa Maria, Santa Maria.

Marasco, D. E., Culligan, P. J., \& Mcgillis, W. R. (2015). Evaluation of common evapotranspiration models based on measurements from two extensive green roofs in New York City. Ecological Engineering, 84, 451-462. http://dx.doi.org/10.1016/j.ecoleng.2015.09.001.

Mentens, J., Raes, D., \& Hermy, M. (2006). Green roofs as a tool for solving the rainwater runoff problem in the urbanized $21 \mathrm{st}$ century? Landscape and Urban Planning, 77(3), 217-226. http:/ / dx.doi.org/10.1016/j.landurbplan.2005.02.010.

Monterusso, M. A., Rowe, D. B., \& Rugh, C. L. (2005). Establishment and persistence of Sedum spp. and native taxa for green roof applications. HortScience, 40(2), 391-396. http:/ /dx.doi.org/10.21273/ HORTSCI.40.2.391.

Peel, M. C., Finlayson, B. L., McMahon, T. A. (2007). Updated world map of the Koppen-Geiger climate classification. Hydrology and Earth System Sciences, 11, 1633-1644. https://doi.org/10.5194/ hess-11-1633-2007.

Pessoa, J. O. (2016). Qualidade e quantidade de águas pluviais escoadas a partir de telhados verdes extensivos em Santa Maria-RS (dissertação de mestrado). Universidade Federal de Santa Maria, Santa Maria.

Poë, S., Stovin, V., \& Berretta, C. (2015). Parameters influencing the regeneration of a green roof's retention capacity via evapotranspiration. Journal of Hydrology (Amsterdam), 523, 356-367. http://dx.doi.org/10.1016/j.jhydrol.2015.02.002.

Rowe, D. B., Monterusso, M. A., Rugh, C. L., \& Words, A. D. I. (2006). Assessment of heat-expanded slate and fertility requirements in green roof substrates. HortTechnology, 16(3), 471-477. http:// dx.doi.org/10.21273/HORTTECH.16.3.0471.

Santos, H. D., Jacomine, P. K. T., Anjos, L. H. C., Oliveira, V. A., Lumbreras, J. F., Coelho, M. R., Almeida, J. A., Araujo Filho, J. C., Oliveira, J. B., \& Cunha, T. J. F. (2018). Sistema Brasileiro de Classificação de Solos. Brasília, DF: Embrapa Embrapa Solos (CNPS).

Schneider, D., Wadzuk, B. M., \& Traver, R. G. (2011). Using a weighing lysimeter to determine a crop coefficient for a green roof to predict evapotranspiration with the FAO Standardized Penman-Monteith Equation. In Proceedings of the World Environmental and Water Resources Congress 2011 (pp. 3629-3638). Reston: ASCE. http://dx.doi.org/10.1061/41173(414)380.
Sia, M. E. (2016). Evapotranspiration from extensive green roofs: influence of calimatological conditions, vegetation type, and substrate depth. London: The University of Western Ontario.

Sims, A. W. (2015). Stormwater management performance of green roofs (Master's thesis). The University of Western Ontario, London.

Sims, A. W., Robinson, C. E., Smart, C. C., Voogt, J. A., Hay, G. J., Lundholm, J. T., Powers, B., \& O’Carroll, D. M. (2016). Retention performance of green roofs in three different climate regions. Journal of Hydrology (Amsterdam), 542, 115-124. http://dx.doi. org/10.1016/j.jhydrol.2016.08.055.

Soulis, K. X., Ntoulas, N., Nektarios, P. A., \& Kargas, G. (2017). Runoff reduction from extensive green roofs having different substrate depth and plant cover. Ecological Engineering, 102, 80-89. http://dx.doi.org/10.1016/j.ecoleng.2017.01.031.

Starry, O., Lea-cox, J., Ristvey, A., \& Cohan, S. (2016). Parameterizing a water-balance model for predicting stormwater runoff from green roofs. Journal of Hydrologic Engineering, 21(12), 04016046. http:/ / dx.doi.org/10.1061/(ASCE)HE.1943-5584.0001443.

Stovin, V., Poë, S., De-Ville, S., \& Berreta, C. (2015). The influence of substrate and vegetation configuration on green roof hydrological performance. Ecological Engineering, 85, 159-172. https://doi. org/10.1016/j.ecoleng.2015.09.076.

Stovin, V., Vesuviano, G., \& Kasmin, H. (2012). The hydrological performance of a green roof test bed under UK climatic conditions. Journal of Hydrology (Amsterdam), 414-415, 148-161. http://dx.doi. org/10.1016/j.jhydrol.2011.10.022.

Tabares-Velasco, P. C., \& Srebric, J. (2012). A heat transfer model for assessment of plant based roo fi ng systems in summer conditions. Building and Environment, 49, 310-323. http://dx.doi. org/10.1016/j.buildenv.2011.07.019.

Taiz, L., \& Zeiger, E. (2004). Fisiologia vegetal (3. ed.). Porto Alegre: Artmed.

Tan, L. C., Tan, P. Y., Wong, N. H., Takasuna, H., Kudo, T., Takemasa, Y., Lim, C. V. J., \& Chua, H. X. V. (2017). Impact of soil and water retention characteristics on green roof thermal performance. Energy and Building, 152, 830-842. http://dx.doi. org/10.1016/j.enbuild.2017.01.011.

Tassi, R., Tassinari, L. C. S., Piccilli, D. G. A., \& Persch, C. G. (2014). Telhado verde: uma alternativa sustentável para a gestão das águas pluviais. Ambiente Construído, 14(1), 139-154. http:// dx.doi.org/10.1590/S1678-86212014000100012.

United Kingdom Accreditation Service - UKAS. (2015). In-house calibration and use of weighing machines (5th ed.). United Kingdom: UKAS.

VanWoert, N. D., Rowe, D. B., Andresen, J. A., Rugh, C. L., \& Xiao, L. (2005). Watering regime and green roof substrate design 
affect Sedum plant growth. HortScience, 40(3), 659-664. http:// dx.doi.org/10.21273/HORTSCI.40.3.659.

Voyde, E. A. (2011). Quantifying the complete bydrologic budget for an extensive living roof. Auckland: The University of Auckland.

Voyde, E., Fassman, E., Simcock, R., \& Wells, J. (2009). Quantifying evapotranspiration rates for New Zealand green roofs. Journal of Hydrologic Engineering, 15(6), 395-403.

Zhang, Q., Miao, L., Wang, X., Liu, D., Zhu, L., Zhou, B., Sun, J., \& Liu, J. (2015). The capacity of greening roof to reduce stormwater runoff and pollution. Landscape and Urban Planning, 144, 142-150. http://dx.doi.org/10.1016/j.landurbplan.2015.08.017.

\section{Authors contributions}

Nathana Karina Swarowski Arboit: Developed the idea for the study, bibliographical research, experimental design, treatment and analysis of data, discussion and interpretation of results, writing and preparation of figures and tables, submission of the article.

Rutineia Tassi: Developed the idea for the study, the experimental design, treatment, discussion and interpretation of results, writing and review of the article.

Tiago Liberalesso: Helped in the development of the experiment and in the review of the article.

Denise Ester Ceconi: Helped in the experimental design.

Daniel Gustavo Allasia Piccili: Assisted in reviewing the article.

Editor in-Chief: Adilson Pinheiro

Associated Editor: Priscilla Macedo Moura 